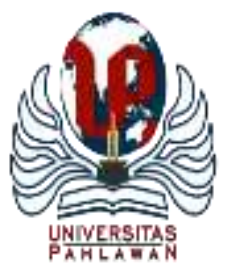

Edukatif : Jurnal Ilmu Pendidikan Volume 3 Nomor 6 Tahun 2021 Halm 4383 - 4391

EDUKATIF: JURNAL ILMU PENDIDIKAN

Research \& Learning in Education

https://edukatif.org/index.php/edukatif/index

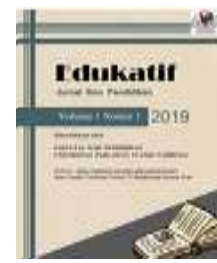

\title{
Analisis Pelaksanaan Pembelajaran Matematika Kelas Tinggi Secara Daring dimasa Pandemi pada Siswa Sekolah Dasar
}

\author{
Andi Lely Nurmaya G ${ }^{1 凶}$, Irsan $^{2}$, Ika Sulastri ${ }^{3}$, Wa Ode Khairin Nisa ${ }^{4}$
}

Universitas Muhammadiyah Buton 1,2,3,4

E-mail : $\underline{\text { nurmaya.aln@gmail.com }}^{1}, \underline{\text { irsanlely @ gmail.com }}^{2}, \underline{\text { Ikasulastri01@ gmail.com }}^{3}$, Ode Nisa@ gmail.com ${ }^{4}$

\begin{abstract}
Abstrak
Matematika adalah salah satu ilmu pengetahuan yang berperan penting dalam kehidupan manusia yang mampu membentuk karakter siswa. Dengan pembelajaran matematika siswa diharapkan mampu mengembangkan pengetahuan dan melatih kemampuan berpikir kreatif mereka penyelesaikan masalah yang dihadapi. Pada saat pembelajaran daring, banyak siswa merasa kesulitan dalam pelaksanaannya, khususnya pada pelajaran matematika. Oleh karena hal tersebut, tujuan dari penelitian ini adalah untuk menganalisis pelaksanaan pembelajaran matematika kelas kelas tinggi secara daring dimasa pendemi pada siswa sekolah dasar. Adapun metode penelitian yang digunakan adalah deskriptif kuantitatif. Populasi dalam penelitian adalah siswa kelas tinggi (IV,V,VI) di Sekolah Dasar Kota Baubau melalui teknik sampling jenuh dimana semua anggota populasi digunakan sebagai sampel. Hasil penelitain yang diperoleh dari angket yang dibagikan adalah pendapat mengenai pembelajaran daring sebayak 17\%, Kemampuan siswa memahami materi pembelajaran yang diajarkan secara daring $24 \%$, Efektifitas penyampaian materi dalam pembelajaran matematika secara daring 19\%, Kendala yang dialami siswa dalam kegiatan pembelajaran matematika secara daring $22 \%$ dan harapan siswa terhadap pelakasanaan pembelajaran matematika secara daring. Pada pelaksanaan pembelajaran matematika secara daring dapat terlihat keaktifan belajar siswa tidak sama seperti pembelajaran dilaksanakan secara langsung (tatap muka) di sekolah, siswa cenderung kurang aktif.
\end{abstract}

Kata Kunci: Pembelajaran, Matematika Kelas Tinggi, Pandemi.

Abstract

Mathematics is one of the sciences that plays an important role in human life that is able to shape the character of students. By learning mathematics, students are expected to be able to develop their knowledge and practice their creative thinking skills in solving the problems they face. During online learning, many students find it difficult to implement it, especially in mathematics. Because of this, the purpose of this study was to analyze the implementation of online high-class mathematics learning during a pandemic for elementary school students. The research method used is descriptive quantitative. The population in this study were high school students (IV, V, VI) at Baubau City Elementary School through a saturated sampling technique where all members of the population were used as samples. The results of the research obtained from the questionnaires distributed are opinions about online learning as much as 17\%, the ability of students to understand learning materials taught online 24\%, the effectiveness of delivering material in online mathematics learning $19 \%$, Constraints experienced by students in online mathematics learning activities $22 \%$ and students' expectations of the implementation of online mathematics learning. In the implementation of online mathematics learning, it can be seen that student learning activities are not the same as learning carried out directly (face to face) in schools, students tend to be less active.

Keywords: Learning, High Grade Mathematics, Pandemic.

Copyright (c) 2021 Andi Lely Nurmaya. G, Irsan, Ika Sulastri, Wa Ode Khairin Nisa $\triangle$ Corresponding author

Email : nurmaya.aln@gmail.com

DOI : https://doi.org/10.31004/edukatif.v3i6.1476

ISSN 2656-8063 (Media Cetak)

ISSN 2656-8071 (Media Online)

Edukatif : Jurnal Ilmu Pendidikan Vol 3 No 6 Tahun 2021 p-ISSN 2656-8063 e-ISSN 2656-8071 
4384 Analisis Pelaksanaan Pembelajaran Matematika Kelas Tinggi Secara Daring dimasa Pandemi pada Siswa Sekolah Dasar-Andi Lely Nurmaya. G, Irsan, Ika Sulastri, Wa Ode Khairin Nisa

DOI: https://doi.org/10.31004/edukatif.v3i6.1476

\section{PENDAHULUAN}

Proses pendidikan mengajarkan peserta didik mengembangkan kemampuannya dalam beradapdasi dengan lingkungannya, sehingga mengakibatkan terjadi perubahan pada diri peserta didik dalam kehidupannya di masyarakat. Kenyataan saat ini di dunia mengalami pandemi yang disebabkan oleh Virus Corona. Terjadinya pandemi Covid-19 di berbagai Negara sangat berdampak pada sektor kehidupan manusia dan Indonesia merupakan salah satu negara yang mengalami pandemi ini. Pandemi Covid-19 mengakibatkan perubahan-perubahan pada sistem pendidikan (Suhardi, Albiy, Gistituati, \& Marsidin, 2021).(Anugrahana, 2020) mengemukakan "proses pembelajaran menjadi terganggu dan tidak dapat dilakukan secara konvensional karena adanya pandemi Covid-19". Dengan adanya kebijakan dari pemerintah di bidang pendidikan Salah satunya adalah melalui surat edaran Kementrian Pendidikan dan Kebudayaan (Kemendikbud) Direktorat Pendidikan Tinggi No 1 tahun 2020 sehingga perubahan terjadi pada berbagai tingkatan satuan pendidikan yang biasanya pembelajaran secara formal dilakukan di sekolah dengan tatap muka menjadi pembelajaran jarak jauh (secara Daring) di rumah masing-masing peserta didik(Aji, Dewi, Kristen, \& Wacana, 2020).

Proses pembelajaran yang dilakukan secara daring merupakan kegiatan belajar secara langsung antara guru dan siswa tetapi dilakukan melalui online dengan akses jaringan internet melalui perangkat computer (PC) ataupun laptop.(Rumengan et al., 2019) mengungkapkan Pembelajaran daring (E-learning) adalah suatu sistem atau konsep pendidikan yang memanfaatkan teknologi informasi dalam proses belajar mengajar. Dalam kegiatan pembelajaran guru dan siswa menggunakan berbagai media pembelajaran diantaranya aplikasi media sosial seperti WA (Whatsapp), Telegram, Aplikasi Zoom, ataupun media platform learning online sehingga guru dapat memastikan kegiatan belajar mengajar tetap terlaksana meskipun terpisah oleh jarak dimana siswa berada di rumah masing-masing(Handarini \& Wulandari, 2020). Pembelajaran daring adalah sebuah pembelajaran yang dilakukan dalam jarak jauh melalui media yang berupa internet dan alat penunjang lainnya seperti telepon seluler dan computer (Arifin \& Chotimah, 2021). (Covid- \& Kusumaningrum, 2020) menyatakan bahwa pembelajaran daring dapat dijadikan sebagai solusi pembelajaran jarak jauh ketika terjadi bencana alam. Pembelajaran online juga dapat mempermudah pelajar dalam mengikuti pembelajaran daring. Seperti yang sudah diterapkan sekarang ini ketika banyak sekolah diliburkan karena untuk mencegah penyebaran Covid-19 dan digantikan dengan pembelajaran daring yang dilakukan dirumah (Sulistiani \& Ulya, 2021). Pembelajaran daring adalah pembelajaran yang menggunakan jaringan internet dengan aksesbilitas, fleksibilitas, dan kemampuan untuk memunculkan berbagai jenis interaksi pembelajaran. Teknologi pembelajaran daring juga dapat mengembangkan kemampuan guru dalam bidang Ilmu Pengetahuan Teknologi (IPTEK) (Logawe \& Hermawan, 2021). (Meta-analisis, Mandailina, \& Pramita, 2021)menyatakan bahwa pembelajaran melalui jaringan memiliki potensi-potensi, antara lain: kebermaknaan belajar, kemudahan mengakses, dan peningkatan hasil belajar. Kemudian menurut (Samarinda, 2021) dalam penelitiannya menyatakan bahwa perkembangan teknologi memberikan perubahan pelaksanaan pengajaran dan pembelajaran.

Matematika adalah salah satu ilmu pengetahuan yang berperan penting dalam kehidupan manusia dan menjadi salah pengetahuan yang mampu membentuk karakter siswa. Dengan pembelajaran matematika siswa diharapkan mampu mengembangkan pengetahuan dan melatih kemampuan berpikir kreatif mereka penyelesaikan masalah yang dihadapi. Pada satuan pendidikan formal, pelaksanaan pembelajaran matematika merupakan mata pelajaran wajib yang dipelajari semua siswa pada setiap jenjang pendidikan dan menjadi dasar dari segala ilmu pengetahuan. (Zakiyah, Usman, \& Gobel, 2021) mengemukakan matematika berasal dari bahasa Latin, matheneim, atau mathema yang berarti belajar atau hal yang dipelajari. Sedangkan dalam bahasa Belanda matematika disebut wiskude atau ilmu pasti yang semuanya berkaitan dengan penalaran. 
Matematika tidak hanya diperlukan dalam dunia pendidikan formal, akan tetapi matematika digunakan dalam kehidupan sehari-hari.

Adapun kemampuan yang harus dimiliki siswa dalam pelajaran matematika diantaranya kemampuan dalam memecahkan masalah dan kemampuan dalam berkomunikasi, karena dengan matematika tejadi proses sosial dimana mereka harus berinteraksi, bekerja sama, dan berkomunikasi antara siswa yang satu dengan lainnya serta dengan gurunya. (Logawe \& Hermawan, 2021) dalam pelajaran matematika, komunikasi guru dengan siswa maupun siswa dengan siswa sangat penting untuk mencapai tujuan pembelajaran. Matematika merupakan mata pelajaran pokok yang wajib dipelajari siswa di sekolah dasar. Matematika merupakan ilmu yang sangat penting untuk dipelajari, ditinjau dari berbagai manfaat yang diberikan untuk memudahkan kita dalam mempelajari materi pembelajaran yang lain ataupun pemanfaatan materi matematika itu sendiri dalam kehidupan sehari-hari (Education et al., 2020). Pada dasarnya pelajaran matematika tidak selalu tentang angka, tetapi banyak kemampuan yang dapat dikembangkan dari pelajaran matematika salah satunya penyelesaian masalah dalam kehidupan sehari-hari. Hal ini sependapat dengan (Chotimah, Ramdhani, Bernard, \& Akbar, 2018) matematika merupakan salah satu pelajaran yang erat kaitannya dengan kehidupan nyata, tidak sedikit hal ataupun masalah yang ada disekeliling kita memerlukan ilmu matematika. Tetapi karena matematika menggunakan banyak rumus nampaknya matematika merupakan salah satu mata pelajaran yang ditakuti dan dianggap rumit serta sulit dipahami oleh beberapa siswa. Hal ini sejalan dengan penelitian yang di lakukan (Fauzy \& Nurfauziah, 2021) bahwa masih banyak siswa yang menganggap matematika sebagai pelajaran yang sulit, sehingga menyebabkan siswa mudah menyerah sebelum mempelajari matematika.

Pelaksanaan pembelajaran matematika secara daring sistem menjadi salah satu solusi untuk mengatasi kesulitan dalam pembelajaran tatap muka dengan adanya aturan social distancing (Penelitian, Kepustakaan, \& Pendidikan, 2020). Oleh sebab itu, pemerintah sangat menganjurkan pembelajaran daring mampu diterapkan di sekolah-sekolah dan melarang aktvitas diluar rumah khususnya bagi siswa. Maka dari itu pembelajaran daring sangat cocok untuk di terapkan dalam sistem pembelajaran di sekolah. Cara tersebut dilakukan supaya pelaksana pembelajaran memiliki berbagai jenis alternatif dalam menyampaikan pembelajaran kepada siswa (Ramanta \& Widayanti, 2020). Tetapi pada kenyataanya sistem pembelajaran daring menjadi salah satu polemic dalam penerapannya terutama pada tingkat sekolah dasar. Hal tersebut dikarenakan pembelajaran daring ini masih dianggap tidak lebih baik dari pada pembelajaran tatap muka yang secara konvensional terutama dalam pembelajaran matematika, selain itu kurangnya persiapan pihak sekolah dan siswa masih belum efektif untuk menjalankannya. Ketidakefektifan ini dikarenakan fasilatas dari pihak sekolah maupun dari pihak siswa kurang memadai. Pembelajaran daring tidaklah mudah, terdapat beberapa faktor yang terlibat diantaranya guru, siswa, bahkan orang tua siswa juga berperan penting dalam terciptanya pembelajaran yang efektif. Selain itu, adanya pembelajaran daring yang terkesan mendadak karena COVID-19 ini juga menyebabkan persiapan yang tidak optimal. Sehingga menyebabkan siswa merasa tidak siap dalam pelaksanaanya, terutama dalam mata pelajaran matematika. Pembelajaran daring ini sangat berdampak bagi seluruh guru dan siswa, karena banyak dari siswa yang tidak memiliki fasilitas untuk menunjang pembelajaran daring seperti handphone, laptop, dan juga terbatasnya kuota.(Fauzy \& Nurfauziah, 2021) bahwa Pelaksanaan pembelajaran daring membutuhkan adanya fasilitas sebagai penunjang, yaitu seperti smartphone, laptop, ataupun tablet yang dapat digunakan untuk mengakses informasi dimanapun dan kapanpun. Kurangnya fasilitas dalam pembelajaran daring yang di terapkan di sekolah sangat berpengaruh pada keefektifan terhadap kemampuan berpikir kreatif matematika siswa dalam belajar, dimana dalam meningkatkan kemampuan berpikir kreatif matematika siswa, biasanya guru melakukan tatap muka dengan siswa, namun dikarenakan pandemi Covid-19 pembelajaran dilakukan secara daring yang menyebabkan pembelajaran matematika kurang efektif bagi siswa. 
Kegiatan belajar yang dilakukan secara daring tetap memuntut keaktifan belajar, partisipasi dan komunikasi interaktif antara guru dan siswa. Aktivitas dalam belajar dirancang dengan baik sehingga tujuan pembelajaran yang di tentukan dapat tercapai (Baety \& Munandar, 2021). Keberhasilan dalam proses pembelajaran dapat dilihat dari pemahaman konsep, penguasaan materi dan prestasi belajar siswa serta ketepatan menjadi faktor penentu keberhasilan pembelajaran. Seorang guru diharapkan dapat memahami berbagai metode ataupun strategi pembelajaran diantaranya juga yang berkaitan dengan model-model pembelajaran. Dalam perencanaan aktivitas belajar mengajar dengan model pembelajaran dan memanfaatkan media pembelajaran untuk memperjelas penyajian pesan dan informasi sehingga dapat meningkatkan proses dan hasil belajar(Turmuzi \& Dasing, 2021). Media pembelajaran juga dapat mengarahkan perhatian siswa sehingga memotivasi siswa dalam belajar yang berdampak pada keaktifan dan hasil belajar.

Dengan adanya fenomena yang terjadi di dunia pendidikan saat ini, untuk melaksanakan pembelajaran daring di masa pandemi covid-19, apakah orang tua siswa mampu menyiapkan perangkat pembelajaran daring, kemudian apakah pembelajaran daring efektif bisa dilakukan oleh guru untuk dapat menumbuhkembangkan pengetahuan dan kemampuan siswa agar tujuan pembelajaran dapat tercapai dengan baik(Pandemi, Sekolah, Atas, Fathonah, \& Bukhori, 2021). Dalam pelaksanaan pembelajaran secara daring yang terkesan mendadak(Rahma, Wulandari, Husna, Ahmad, \& Yogyakarta, 2021). Hal ini terlihat dengan berbagai kendala yang dihadapi guru maupun siswa saat pelaksanaan pembelajaran daring khususnya mata pelajaran matematika. Dimana pada proses pembelajaran matematika jika diajarkan kepada siswa secara daring kurang efektif. Selain itu, adanya pembelajaran daring yang terkesan mendadak karena COVID-19 ini juga menyebabkan persiapan yang tidak optimal. Sehingga menyebabkan siswa merasa tidak siap dalam pelaksanaanya, terutama dalam mata pelajaran matematika kelas tinggi di Sekolah Dasar.

Berdasarkan permasalahan di atas, diperlukan kajian untuk mengetahui keefektifan dalam pembelajaran daring matematika yang dilaksanakan di jenjang SD (Sekolah Dasar). Hal tersebut yang mendasari peneliti untuk menganalisis pelaksanaan pembelajaran matematika kelas Tinggi secara daring pada siswa sekolah dasar dimasa pandemi Covid-19. Sehingga, dalam artikel ini dilakukan analisis terhadap pelaksanaan pembelajaran matematika secara daring. Peneliti merasa perlu melakukan penelitian ini karena kemampuan siswa dalam pembelajaran matematika adalah salah satu tujuan penting yang harus dicapai dalam proses pembelajaran. walaupun pada masa pandemi ini proses pembelajaran berubah dari biasanya secara langsung (tatap muka) menjadi daring atau secara virtual. Hasil penelitian ini diharapkan dapat bermanfaat dan memberikan informasi kepada guru dan pihak sekolah terkait kemampuan siswa dalam pembelajaran daring.

\section{METODE PENELITIAN}

Penelitian ini dilaksanakan pada satuan pendidikan Sekolah Dasar di Kota Baubau Provinsi Sulawesi Tenggara. Penelitian ini berlangsung pada semester genap tahun pelajaran 2020/2021 dari bulan Maret sampai April 2021. Adapun Jenis penelitian yang digunakan merupakan penelitian deskriptif kuantitatif. Populasi dalam penelitian adalah siswa kelas tinggi (IV,V,VI). Melalui teknik sampling jenuh dimana semua anggota populasi digunakan sebagai sampel. Teknik pengumpulan data dilakukan dengan menggunakan instrumen penelitian yang berupa observasi dalam penelitian untuk mengetahui kemampuan guru dalam mengelola pembelajaran, dan angket dalam penelitian untuk mengetahui respon siswa dengan memberikan lembar pernyataan atau pertanyaan yang berbentuk pilihan jawaban yang ditetapkan oleh peneliti yang sebelumnya sudah di uji validitasnya. Analisis data kualitatif mencakup 1) proses mencari dan menyusun secara sistematis data yang diperoleh dari hasil angket dan wawancara; 2) reduksi data; 3) penyajian data; dan 4) conclusion drawing atau verifikasi. 
4387 Analisis Pelaksanaan Pembelajaran Matematika Kelas Tinggi Secara Daring dimasa Pandemi pada Siswa Sekolah Dasar - Andi Lely Nurmaya. G, Irsan, Ika Sulastri, Wa Ode Khairin Nisa

DOI: https://doi.org/10.31004/edukatif.v3i6.1476

\section{HASIL DAN PEMBAHASAN PENELITIAN}

Sampel dalam penelitian ini berjumlah 60 siswa, yang dipilih dari kelas tinggi (IV, V, VI) Sekolah Dasar Kota Baubau yang masing-masing berjumlah 20 siswa yang mewaakili setiap tingkatan kelas. Pada proses pembelajaran matematika perlu memperhatikan tujuan pebelajaran yang hendak dicapai meskipun proses pembelajaran tidak berlangsung secara langsung (tatap muka), Berdasarkan Permendikbud Nomor 58 Tahun 2014 tentang tujuan pembelajaran matematika satu dari delapan tujuan pembelajaran matematika adalah agar siswa mempunyai kemampuan pemecahan masalah matematika. Hal ini sesuai dengan standar kemampuan matematis yang ditetapkan oleh National Council of Teachers of Mathematics (NCTM) yang salah satunya adalah kemampuan pemecahan masalah (problem solving). Upaya-upaya pengkajian terhadap kemampuan siswa pada dasarnya banyak dilakukan seperti kemampuan komunikasi matematis, kemampuan berpikir kreatif ataupun kemampuan penalaran. Adapun setiap satuan pendidikan memiliki persoalan yang berbeda-beda yang butuh penangkajian dan penanganan khusus, seperti halnya yang terjadi di kelas tinggi Sekolah Dasar Kota Baubau. Hasil wawancara dan observasi bersama guru mata pelajaran matematika/wali kelas memberikan informasi bahwa siswa masih mengalami kendala untuk menyelesaikan soal yang berkaitan dengan pemecahan masalah. Kendala yang dialami siswa yaitu memahami materi pembelajaran. sedang pada masa pembelajaran daring ini, guru lebih sering memberikan soal rutin kepada siswa berupa soal latihan biasa yang banyak terdapat dalam buku teks dan hanya digunakan untuk dapat melatih siswa menggunakan prosedur atau metode yang sedang dipelajari di kelas. Akibatnya, kemampuan pemecahan masalah siswa tidak terasah karena tidak terbiasa mengerjakan soal pemecahan masalah.

Dalam penelitian ini instrumen pelaksanan pembelajaran matematika secara daring pada angket terdapat 5 aspek yang diamati. Jumlah alternatif jawaban mempunyai rentang skor 1 sampai 4 dimana skor tertinggi 4 dan skor terendah 1 , keseluruhan pernyataan bersifat pernyataan positif.

Tabel 1. Kisi-kisi Angket

\begin{tabular}{|c|c|c|c|}
\hline No & Aspek Yang dinilai & $\begin{array}{l}\text { Nomor } \\
\text { Angket }\end{array}$ & $\begin{array}{l}\text { Persentas } \\
\text { e\% }\end{array}$ \\
\hline \multirow[t]{4}{*}{1} & Pendapat mengenai pebelajaran daring & & \\
\hline & Senang & 1 & $2 \%$ \\
\hline & Biasa saja & 2 & $11 \%$ \\
\hline & Tidak senang & 3 & $4 \%$ \\
\hline \multirow[t]{4}{*}{2} & $\begin{array}{l}\text { Kemampuan siswa memahami materi pembelajaran yang diajarkan } \\
\text { secara daring }\end{array}$ & & \\
\hline & Paham & 4 & $8 \%$ \\
\hline & Kurang paham & 5 & $12 \%$ \\
\hline & Tidak Paham & 6 & $4 \%$ \\
\hline \multirow[t]{4}{*}{3} & $\begin{array}{l}\text { Efektifitas penyampaian materi dalam pembelajaran matematika } \\
\text { secara daring }\end{array}$ & & \\
\hline & Efektif & 7 & $5 \%$ \\
\hline & Kurang efektif & 8 & $10 \%$ \\
\hline & Tidak Efektif & 9 & $4 \%$ \\
\hline \multirow[t]{3}{*}{4} & $\begin{array}{l}\text { Kendala yang dialami siswa dalam kegiatan kegiatan pembelajaran } \\
\text { matematika secara daring }\end{array}$ & & \\
\hline & Koneksi jaringan & 10 & $4 \%$ \\
\hline & Penggunaan kuota internet & 11 & $9 \%$ \\
\hline
\end{tabular}


4388 Analisis Pelaksanaan Pembelajaran Matematika Kelas Tinggi Secara Daring dimasa Pandemi pada Siswa Sekolah Dasar - Andi Lely Nurmaya. G, Irsan, Ika Sulastri, Wa Ode Khairin Nisa

DOI: https://doi.org/10.31004/edukatif.v3i6.1476

\begin{tabular}{llcc} 
No & \multicolumn{1}{c}{ Aspek Yang dinilai } & $\begin{array}{c}\text { Nomor } \\
\text { Angket }\end{array}$ & $\begin{array}{c}\text { Persentas } \\
\text { e\% }\end{array}$ \\
\hline & Perangkat pembelajaran yang digunakan & 12 & $3 \%$ \\
\hline $\begin{array}{l}\text { Pemberiaan tugas yang terlalu banyak agar tidak malas untuk } \\
\text { belajar }\end{array}$ & 13 & $4 \%$ \\
\hline Kesesuaian media pembelajaran & 14 & $2 \%$ \\
\hline $5 \quad \begin{array}{l}\text { Harapan siswa terhadap pelakasanaan pembelajaran matematika } \\
\text { secara daring }\end{array}$ & 15 & $18 \%$ \\
\hline Jumlah & 15 & $100 \%$ \\
\hline
\end{tabular}

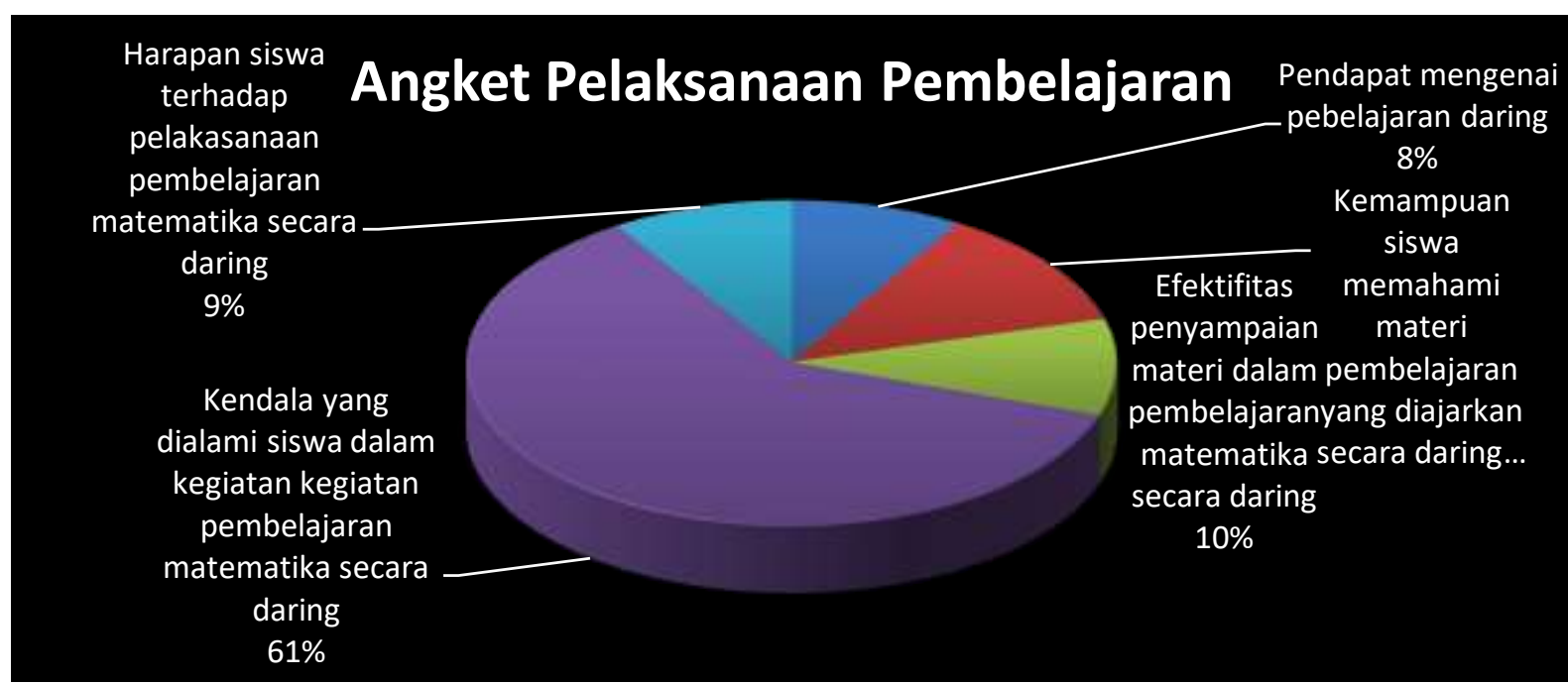

Berdasarkan gambar pada diagram tersebut, angket pertama yang diberikan kepada responden adalah meminta pendapat bagaimana pelaksanaan pembelajaran daring selama masa pandemi sebanyak $17 \%$, sebanyak $11 \%$ siswa mempunyai perasaan yang biasa saja terhadap pelaksanaan pembelajaran matematika secara daring, sebanyak 4\% siswa tidak senang dan sebanyak 2\% siswa senang mengikuti pelajaran. Melihat dari jawaban yang diberikan diatas hanya sedikit saja siswa yang merasa senang mengikuti pelajaran matematika secara daring alasan mereka adalah proses pembelajarannya menggunakan perangkat teknologi dan dilaksanakan di rumah atau dimana saja tanpa harus ke sekolah sedangkan lebih banyak siswa yang merasa biasa saja dalam mengikuti pembelajaran daring dirumah dan hanya mengikuti himbauan pemerintah dan guru. Siswa yang merasa tidak senang mengikuti pelajaran daring memberikan alasan bahwa pembelajaran daring membosankan karena tidak ada interaksi langsung dengan guru dan teman seperti sekolah tatap muka serta terkadang ada tugas yang diberikan tidak dimengerti untuk dikerjakan.

Berdasarkan Angket kedua yang diberikan yaitu kemampuan siswa dalam memahami materi pembelajaran yang diajarkan secara daring sebanyak 24\%, sebanyak $12 \%$ siswa kurang paham dengan pembelajaran matematika yang dilakukan secara daring, sebanyak $8 \%$ siswa paham, dan sebanyak $4 \%$ tidak paham. Dilihat dari jawaban diatas kebanyakan siswa kurang paham dengan pembelajaran matematika yang dilakukan secara daring. Sebenarnya sebelum pembelajaran daring pun tingkat pemahaman siswa terhadap matematika sudah rendah. Hal tersebut terbukti dari hasil ujian matematika siswa yang dari tahun ke tahun yang semakin menurun. Senada dengan penelitian (Khotimah \& Balikpapan, 2019), menjelaskan bahwa hasil UN tahun 2018, matematika menjadi salah satu bidang studi yang nilai rata-ratanya mengalami penurunan setiap tahunnya. Hal ini dikarenakan siswa tersebut tidak bertemu langsung dengan guru kelas yang 
berdampak pada kesulitan siswa dalam memahami pelajaran dan menanyakan materi pelajaran yang tidak dimengerti, meskipun siswa bisa menanyakan melalui chat whatsapp, voice note whatsapp, maupun video call whatsapp dengan gurunya secara daring tetapi masih terdapat siswa masih kesulitan dan memerlukan bimbingan guru. Hal ini sesuai dengan pendapat (Amelia, Chotimah, \& Putri, 2021) Siswa masih kesulitan untuk memahami materi dan masih memerlukan bimbingan guru sehingga siswa sulit belajar secara mandiri. Kebanyakan dari siswa kurang pahami adalah langkah-langkah dalam pengerjaan soal matematika. Terdapat juga siswa yang paham dengan proses pembelajaran matematika secara daring ini. Siswa tersebut dapat dengan mudah mengakses video pembelajaran seperti pembahasan yang diberikan guru yang terdapat pada youtube apabila siswa tersebut menemukan kesulitan dalam mempelajari materi dan mengerjalan soal-soal matematika. Tetapi untuk mengakses youtube memerlukan kuota dan sinyal yang bagus, maka dari itu banyak dari siswa tidak bisa mengakses youtube karena keterbatasan kuota dan buruknya sinyal dilingkunganna.

Berdasarkan angket ketiga yang dibagikan yakni bagaimana efektifitas penyampaian materi dalam kegiatan pembelajaran matematika secara daring sebanyak 19\%, sebanyak $10 \%$ siswa menjawab kurang efektif, 5\% siswa menjawab efektif dan $4 \%$ siswa menjawab tidak efektif. Dilihat dari jawaban diatas bahwa pembelajaran matematika secara daring kurang efektif. hal ini dikarenakan terdapat faktor yang mempengaruhi jalannya pembelajaran matematika secara daring, seperti fasilitas pendukung pembelajaran, jaringan internet yang tidak stabil serta media pebelajaran yang digunakan kurang medukung dan menarik perhatian belajar siswa dan berdampak pada kesulitan siswa untuk memahami materi. Hal ini sejalan dengan penelitian yang dilakukan (Covid-, Tasdik, \& Amelia, 2021) bahwa pelajaran matematika tidak cocok dijelaskan lewat pembelajaran daring karena sulitnya memahami pelajaran matematika. Serta masih terdapat siswa yang memberikan penilaian bahwa pembeajaran daring kurang efektif disebabkan kurangnya control dari guru.

Berdasarkan angket ke empat yang diberikan yakni bagaimana kendala yang dialami siswa dalam kegiatan pembelajaran matematika secara daring sebanyak 22\%, sebanyak $4 \%$ mempermasalahkan koneksi jaringan, sebanyak 9\% mengalami kendala penggunaan kuota, sebanyak 3\% mengalami kendala terhadap perangkat pembelajaran yang diguunakan. Berdasarkan jawaban yang diberikan responden kendala yang terbesar dialami adalah penggunaan kuota yang sangat besar karena semua materi dan tugas yang diberikan harus diakses menggunakan internet sementara itu penghasilan orang tua siswa yang tidak merata menjadi factor dominan dalam pembelian kuota belajar. Sementara itu terdapat jaga responden yang mempermasalahkan koneksi jaingan internet yang tidak stabil. yang dapat mengganggu proses pembelajaran. Hal tersebut senada dengan yang diungkapka (Eskploratif, 2020), menyatakan bahwa jaringan internet merupakan faktor penting bagi lingkungan pembelajaran daring

Berdasarkan angket terakhir yang diberikan yakni bagaimana harapan siswa terhadap pelaksanaan pembelajaran mstematika secara daring sebanyak $18 \%$. Responden berharap guru memberikan pendampingan khusus kepada siswa yang masih kurang memahami materi yang diberikan serta penjelasan berulang meskipun materi telah lewat. Menurut (Setiawan \& Pamulang, 2020) mengemukakan bahwa sistem pembelajaran daring mengurangi interaksi sosial antara pendidik dan peserta didik yang berakibat pada kurangnya kontrol akademik dan sosial. Guru diharapkan dapat memilih metode pembelajaran yang tepat dan sesuai dengan keadaan pembelajaran daring serta menyajikan materi lebih kreatif salah satunya dengan menggunakan media pembelajaran yang sesuai agar siswa lebih tertarik untuk mengikuti pembelajaran. Upaya mengatasi permasalahan pembelajaran daring salah satunya dengan cara mendorong guru untuk kreatif dan inovatif dalam menciptakan pembelajaran daring yang menarik bagi siswa (Anugrahana, 2020). 
4390 Analisis Pelaksanaan Pembelajaran Matematika Kelas Tinggi Secara Daring dimasa Pandemi pada Siswa Sekolah Dasar - Andi Lely Nurmaya. G, Irsan, Ika Sulastri, Wa Ode Khairin Nisa

DOI: https://doi.org/10.31004/edukatif.v3i6.1476

\section{KESIMPULAN}

Pada pelaksanaan pembelajaran matematika secara daring dapat terlihat keaktifan belajar siswa tidak sama seperti pembelajaran dilaksanakan langsung disekolah, siswa cenderung kurang aktif. Adapun pembelajaran matematika dilakukan secara daring di kelas tinggi (IV, V danVI) pada sekolah-sekolah dasar di Kota Baubau selama masa pandemic covid-19, sesuai dengan hasil wawancara yang dilakukan bersama guru kelas di Sekolah Dasar Negeri Kota Baubau diketahui faktor yang mengakibatkan keaktifan belajar siswa lebih rendah pada pembelajaran daring antara lain yaitu : 1) tidak semua peserta didik memiliki fasilitas pembelajaran yang menunjang untuk dapat mengakses pembelajaran secara daring, 2) pengetahuan siswa yang terbatas dalam penggunaan alat komunikasi dan cara mengakses di jaringan internet, 3) belum adanya kesedaran dari orangtua siswa terkait pentingnya pembelajaran daring, 4) lokasi siswa yang belum memiliki jaringan internet yang stabil. Beberapa siswa belum memiliki fasilitas yang memadai untuk mendukung proses pembelajaran online, apalagi dengan jaringan internet yang buruk sehingga menyulitkan siswa untuk mengikuti pembelajaran online yang harus selalu terkoneksi dengan internet. Selain penyampaian materi, guru dituntut lebih kreatif agar tidak memicu kejenuhan dan kemalasan dalam proses pembelajaran online. Komunikasi siswa yang terbatas dengan guru menyebabkan mereka sulit memahami materi pembelajaran matematika.

\section{UCAPAN TERIMA KASIH}

Ucapan terimakasih peneliti sampaikan kepada beberapa pihak yang sudah membantu dalam menyelesaikan penelitian ini. Dan juga kepada pihak jurnal Edukatif yang telah membantu dalam mempublish artikel.

\section{DAFTAR PUSTAKA}

Aji, W., Dewi, F., Kristen, U., \& Wacana, S. (2020). Dampak Covid-19 Terhadap Implementasi Pembelajaran Daring Di. 2(1), 55-61.

Amelia, R., Chotimah, S., \& Putri, D. (2021). Pengembangan Bahan Ajar Daring Pada Materi Geometri Smp Dengan Pendekatan Project Based Learning Berbantuan Software Wingeom. 05(01), 759-769.

Anugrahana, A. (2020). Hambatan, Solusi Dan Harapan: Pembelajaran Daring Selama Masa Pandemi Covid-19 Oleh Guru Sekolah Dasar. 282-289.

Arifin, M., \& Chotimah, S. (2021). Analisis Efektifitas Pembelajaran Matematika Secara Daring Siswa Smp Di Kabupaten Bekasi Selama Masa Pandemi Covid-19. 05(03), 2452-2459.

Baety, D. N., \& Munandar, D. R. (2021). Edukatif: Jurnal Ilmu Pendidikan Analasis Efektifitas Pembelajaran Daring Dalam Menghadapi Wabah Pandemi Covid-19. 3(3), 880-889.

Chotimah, S., Ramdhani, F. A., Bernard, M., \& Akbar, P. (2018). Pengaruh Pendekatan Model-Eliciting Activities Terhadap Kemampuan Berpikir Kritis Matematik Siswa. 01(02), 68-77.

Covid-, P., \& Kusumaningrum, B. (2020). Apakah Pembelajaran Matematika Secara Daring Efektif ? ( Studi Kasus Pada Pembelajaran Selama Masa. 11(2), 136-142.

Covid-, P., Tasdik, R. N., \& Amelia, R. (2021). Kendala Siswa Smk Dalam Pembelajaran Daring Matematika Di Situasi. 05(01), 510-521.

Education, J. O., Nurmaenah, N. C., Aginai, S., Chotimah, S., Tengah, C., Cimahi, K., \& Barat, J. (2020). Kpk Dan Fpb Menggunakan Pendekatan Saintifik Berbantuan Aplikasi Visual Basic Excel ( Vbe ). 02(04), 275-282.

Eskploratif, S. (2020). Keuntungan, Kendala Dan Solusi Pembelajaran Online Selama Pandemi Covid-19: 
4391 Analisis Pelaksanaan Pembelajaran Matematika Kelas Tinggi Secara Daring dimasa Pandemi pada Siswa Sekolah Dasar - Andi Lely Nurmaya. G, Irsan, Ika Sulastri, Wa Ode Khairin Nisa DOI: https://doi.org/10.31004/edukatif.v3i6.1476

Studi Ekploratif Di Smpn 3 Bae Kudus Lina Handayani. 1(2), 15-23.

Fauzy, A., \& Nurfauziah, P. (2021). Kesulitan Pembelajaran Daring Matematika Pada Masa Pandemi Covid19 Di Smp Muslimin Cililin. 05(01), 551-561.

Handarini, O. I., \& Wulandari, S. S. (2020). Pembelajaran Daring Sebagai Upaya Study From Home ( Sfh ) Selama Pandemi Covid 19 Pembelajaran Daring Sebagai Upaya Study From Home ( Sfh ) ... .. 8(1), 496-503.

Khotimah, H., \& Balikpapan, U. (2019). Faktor-Faktor Yang Memengaruhi Belajar. 2(2), 116-123.

Logawe, R., \& Hermawan, D. (2021). Jurnal Serunai Matematika Jurnal Serunai Matematika. 13(1), 55-61.

Meta-Analisis, S., Mandailina, V., \& Pramita, D. (2021). Pembelajaran Daring Dalam Meningkatkan Motivasi Dan Hasil Belajar Peserta Didik Selama Pandemi Covid-19 : 03(02), 120-129.

Pandemi, S., Sekolah, C.- Di, Atas, M., Fathonah, U., \& Bukhori, H. A. (2021). Edukatif: Jurnal Ilmu Pendidikan Analisis Kesulitan Siswa Dalam Pelaksanaan Pembelajaran Bahasa Jerman Secara Daring. 3(4), 1152-1160.

Penelitian, J. H., Kepustakaan, K., \& Pendidikan, B. (2020). Jurnal Kependidikan: 6(2), 165-175.

Rahma, F. N., Wulandari, F., Husna, D. U., Ahmad, U., \& Yogyakarta, D. (2021). Edukatif: Jurnal Ilmu Pendidikan Pengaruh Pembelajaran Daring Di Masa Pandemi Covid-19 Bagi Psikologis Siswa Sekolah Dasar. 3(5), 2470-2477.

Ramanta, D., \& Widayanti, F. D. (2020). Pembelajaran Daring Di Sekolah Menengah Kejuruan Putra Indonesia Malang Pada Masa Pandemi Covid-19. (5).

Rumengan, I. M., Salmon, A., Lumenta, M., Diane, S., Paturusi, E., Elektro, T., ... Manado, J. K. B. (2019). Pembelajaran Daring Pendidikan Dan Pelatihan Aparatur Sipil Negara Badan Pengembangan Sumber Daya Manusia Papua Barat. 14(3), 303-312.

Samarinda, I. (2021). Zoom Meeting Vs Google Classroom: Perbedaan Hasil Belajar Matematika Berdasarkan Platform Pembelajaran Daring. 8(1), 61-68.

Setiawan, T. H., \& Pamulang, U. (2020). Efektifitas Penerapan Blended Learning Dalam Mahasiswa Melalui Jejaring Schoology Di Masa Pandemi Covid-19. 3(5), 493-506. Https://Doi.Org/10.22460/Jpmi.V3i5.493-506

Suhardi, M., Albiy, R., Gistituati, N., \& Marsidin, S. (2021). Edukatif: Jurnal Ilmu Pendidikan Analisis Dampak Regulasi Pemerintah Terhadap Moda Belajar Daring Di Rumah Bagi Pelaku Pendidikan Di Madrasah Pada Masa Pandemi Covid-19. 3(4), 1849-1858.

Sulistiani, I., \& Ulya, H. (2021). Edukatif: Jurnal Ilmu Pendidikan Kemampuan Komunikasi Matematis Siswa Sekolah Dasar Melalui Pembelajaran Daring. 3(4), 2057-2066.

Turmuzi, M., \& Dasing, A. S. H. (2021). Edukatif: Jurnal Ilmu Pendidikan Analisis Kesulitan Belajar Mahasiswa Secara Online (E-Learning ) Selama Masa Pandemi Covid-19. 3(3), 900-910.

Zakiyah, S., Usman, K., \& Gobel, A. P. (2021). Deskripsi Kemampuan Pemecahan Masalah Matematika Melalui Pembelajaran Daring Pada Materi Persamaan Kuadrat. 2(1), 28-35. 